asphyxia-resistant contraction by dinitrophenol is favoured by keeping the $p H$ of the saline at 6.5 (phosphate buffer). Thus formation of adenosine triphosphate is necessary not only for relaxation, but also for keeping the muscle relaxed.

Department of Physiology,

INDERJIT SINGH

Medical College, Agra.

${ }^{1}$ Singh, S. I., and Singh, I., Nature, 166, 647 (1950).

'Singh, S. I., and Singh, I., Nature, 168, 829 (1951).

${ }^{3}$ Singh, S. I., and Singh, I., Proc. Ind. Acad. Sci., 33, 184 (1951). "Singh, I, Singh, S. I., and Dhalla, N. S., Amer. J. Physiol. 200

\section{Toxicity of Endotoxin and Snake Venom in the Hagfish}

REACTIONS to parenteral administration of endotoxin in mammals include pyrexia, leukopania followed by leukocytosis, vasodilation, and irrevorsible shock ${ }^{1}$. Spink ${ }^{2}$ reviowed the actions of snake venom and endotoxin, and concluded that their mechanism of action is similar; however, in recont studies Condie et al. ${ }^{3}$ showed that there are few parallels between the biological responses of rabbits to Escherichia coli endotoxin and Agkistrodon piscivorus venom and that the two toxins are distinct immunochemically.

Stetson ${ }^{4}$ postulated that the reactions to endotoxin may reflect hypersensitivity in animals the enteric flora of which include Gram-negative organisms. Since earlier studies in the California hagfish, Eptatretus stoutii, indicated that this primitive vertebrate is essentially anergic and unable to develop either immediate or delayed hypersensitivity to bacterial or virus antigens, we felt that a comparison of the toxic action of snake venom and endotoxin in this species would be of interest.

Freshly obtained California hagfish, weighing 30-80 gm., were kept in well-aerated sea-water, maintained at $10^{\circ} \mathrm{C}$., for a preliminary $24-\mathrm{hr}$. observation period, and thon divided into groups of two animals per dose of toxin. The doses of Agkistrodon piscivorus (water moccasin) and Naja flava (yollow cobra) venoms and Escherichia coli endotoxin wero made up to $2 \mathrm{ml}$. volumes in 0.9 per cont saline, and injected into the subdermal lateral sinuses in the tail region of the fish, anterior to the caudal heart. This approximated an intravenous injection in this animal, which has an intermediate-type open circulation, with roturn vessels similar to Amphioxus. Ten-fold variations in dosage were studied (Table 1), and dramatic differences in response to endotoxin and snake venoms were noted.

Endotoxin, even in the $100 \mathrm{mgm}$. dose, failed to produce a detectable reaction in the hagfish, and the animals romained coiled up, their normal attitude when undisturbed. There were no observable differences between these endotoxin-treated fish and the control animals receiving $2 \mathrm{ml}$. of 0.9 per cent saline. By contrast, all doses of the venoms, except $1 \mathrm{mgm}$. of Agkistrodon piscivorus venom, were lethal within $5 \mathrm{hr}$., and the highost doses produced death within $30 \mathrm{~min}$. The dying animals uncoiled to a straightened position, and swimming movements stopped. The complete suppression of these movements suggests action of the venom on the nervous system, since Campbell ${ }^{6}$ has shown that swimming movements of segments continue after the hagfish spinal cord is sectioned. The isolated aneural heart of the hagfish has been studied by one of us (D. J.) $)^{7}$, and the effects
Table 1. REspoNse TO ENDOTOXIN AND SNAKE VenOMS IN THE Toxin dose
Hagkistrodon piscivorus venom (mgm.)
1
10
100
50
100
1,000
1
10
100 $1 \mathrm{hr}$. Deaths* $24 \mathrm{hr}$. $48 \mathrm{hr}$.

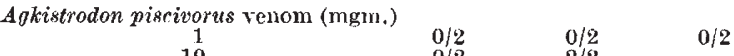
$\begin{array}{cccc}10 & 0 / 2 & 2 / 2 & - \\ 100 & 2 / 2 & - & - \\ \text { Naja flava venomi }(\gamma) & 2 / 2 & - & - \\ 50 & 2 / 2 & - & - \\ 100 & 2 / 2 & - & - \\ 1,000 & 0 / 2 & 0 / 2 & 0 / 2 \\ \text { Escherichia coli endotoxin (mgm.) } & 0 / 2 & 0 / 2 & 0 / 2 \\ 1 & 0 / 2 & 0 / 2 & 0 / 2\end{array}$

* No. of deaths within the period specified after administration of the toxin.

Table 2. Respoxsf to FNDOtoxin anp SNake Venoms in THE

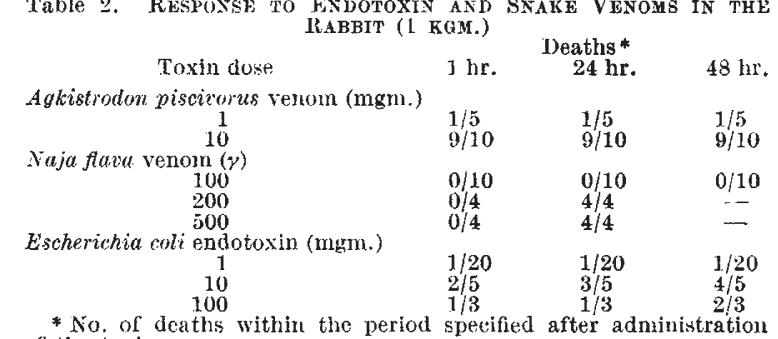
of the toxin.

of snake venom on this organ are now being tested and will be reportod later.

That a $100-\mathrm{mgm}$. dose of endotoxin was without effect in these animals is of interest when compared to the effect in rabbits (Tablo 2). The dose in the hagfish is equivalent to about $1.5 \mathrm{gm} . / \mathrm{kgm}$., and the consistent lethal effect of $1 / 10$, and often of $1 / 100$, of that amount in rabbits is important in dissociating the activities of endotoxin and snake vonom.

The hagfish may be immune to endotoxin because of unknown natural or tissue inhibitors. Alternatively, they may be able to broak endotoxins down to less toxic materials. Howcver, in view of the extremely high doses of endotoxin used in this study, we believe that these hypotheses are less attractive than the Stetson theory that reactions to endotoxin in mam. mals are a result of hypersensitivity to the products of gut traet flora. This hypothesis could be tested further in germ-free mammals using toxins and dosages comparable with those used in this work.

These investigations were aided by grants from the U.S. Public Health Sorvice, American Heart Association, Minnesota Heart Association and the National Foundation.

\section{Ben W. Papermaster* RICHARD M. CONDIE $\dagger$ \\ ROBERT A. GOOD}

Pediatric Research Laboratories, Variety Club Heart Hospital, University of Minnesota, Minneapolis.

DAVID JEN
Scripps Institution of Oceanography,
University of California, La Jolla.

* U.S. Public Health Service trainee.

$\dagger$ Research Associate Cardiovascular Clinical Research Center, grant No. 6314 .

American Legion Memorial Heart research professor of pediatries. $\$$ Advanced Research Fellow, $\Lambda$ merican Heart Association.

'Thomas, I., Ann. Rev. Physiol., 16, 467 (1954).

"Spink, W. W., Yale J. Biol. and Med, 30, 355 (1958).

${ }^{3}$ Condie, R. M., Staab, E. V., and Good, R. A., J. Exp. Med., 115, $563(1962)$.

${ }^{4}$ Stetson, jun., C. A., J. Exp. Med., 101, 421 (1955).

"Yapermaster, B. W., Condie, R. M., and Good, R. A. (to be submitted).

' Campbell, 13., J. Neurophysiol., 3, 323 (1940).

'Jensen, D., Comp. Biochem. Physiol, 2, 181 (1961). 